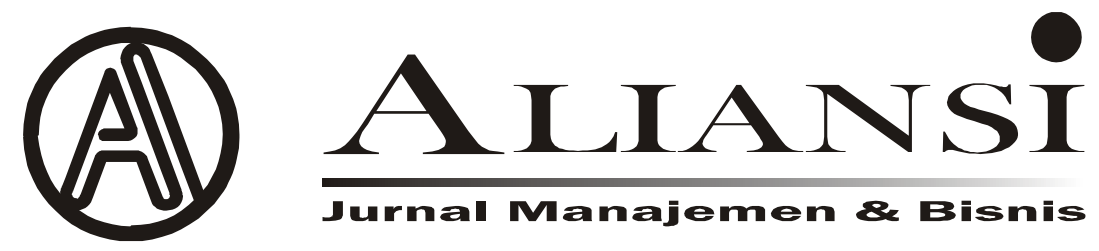

\title{
ANALISIS PENGARUH KUALITAS PRODUK, HARGA DAN IKLAN TERHADAP KEPUASAN PEMBELIAN PADA PT. ASKOTAMA INTI NUSANTARA
}

Oleh : Bambang Ermansyah Saragih

email : bambang.ermansyahsaragih@stimaimmi.ac.id

ABSTRACT

The development of the business world in Indonesia iscurrently growing rapidly, considering that it has entered the era of globalization so that the business world is required to develop rapidly. Consumers prioritize product quality, affordable prices and the company's advertisements are not excessive. Creating purchase satisfaction is a challenge for entrepreneurs because a buyer is now increasinglycritical in choosing the type of product and must match his expectations. The purpose of this study is to determine: Analysis of the Effect of Product Quality, Price and Advertising on Purchase Satisfaction at PT. Askotama IntiNusantara. "The sampling technique used in this study the author uses the Random Sampling technique (Randomlyon All Consumers) where each member of the population has the same opportunity to be selected as the overallsample, but the sample in this study is the entire population that is sampled. "The results obtained that partially and simultaneously there is a positive and significant influence between Product Quality, Price, Advertising on Purchase Satisfaction.

Keywords: Product Quality, Price, Advertising and Purchase Satisfaction.

\section{PENDAHULUAN}

\section{Latar Belakang Masalah}

Perkembangan teknologi yang serba canggih seperti saat ini khususnya teknologi komunikasi dan informasi sangat berperan di Indonesia hal ini merupakan suatu tantangan bagi perusahaan adalah untuk menyiapkan karyawan yang berkualitas dalam memberikan pelayanan agar kepuasan pembelian dapat dicapai akan lebih optimal. Pemasaran atau marketing merupakan sebuah aktivitas manusia yang fundamental yang sangat menunjang serta memperlancar proses pertukaran. Aktivitas pemasaran secara langsung akan membantu meningkatkan hasil penjualan produk atau jasa tertentu yang dihasilkan oleh suatu unit bisnis atau organisasi di berbagai pasar sasaran yang ditujunya. Pemasaran barang dan jasa cenderung berbeda. Pemasaran jasa tidak bisa di identifikasikan dengan jelas gambaran produknya. Kita bisa memberikan contoh barangnya dan spesifikasi yang dimiliki. Sedangkan jasa agak unik untuk di identifikasikan. Jasa sering kali baru terlihat bila dikaitkan dengan suatu hubungan langsung (interpersonal) misalnya antara produsen dengan pembeli.

Fenomena pada saat ini penerapan protokol kesehatan buat konsumen yaitu wajib menggunakan masker, mencuci tangan, jaga jarak dan wajib dicek suhu untuk mengetahui kondisi tubuh sedang fit atau tidak apabila konsumen datang ke perusahaan tidak menggunakan masker maka pihak perusahaan wajib menolak dan tidak diperkenankan masuk. Penerpaan protokol kesehatan buat perusahaan sendiri yaitu menyediakan puang tunggu dengan menggunakan metode jaga jarak dan adanya tanda pembatas untuk segi pembayaran di utamakan tidak menggunakan uang cash melainkan menggunakan aplikasi pay untuk mengurangi kontak fisik kepada pkonsumen, kedua perusahaan menyediakan ruangan dan selalu jaga jarak buat konsumen satu dan lainya, setiap ruangan disediakan botol disenfektan guna untuk selalu menghindari adanya virus Covid 19. Protokol kesehatan juga diterapkan pada setiap karyawan, bagi staf semua wajib menggunakan masker, untuk menjaga kebersihan dan mengutamakan protokol kesehatan, bagi karyawan sendiri sangatlah ketat untuk mencegah penularan virus covid 19.

Kualitas Produk (Product Quality) adalah kemampuan suatu produk untuk melaksanakan fungsinya meliputi, daya tahan keandalan, ketepatan kemudahan operasi dan perbaikan, serta atribut bernilai lainnya. Untuk meningkatkan kualitas produk perusahaan dapat menerapkan program "Total 
Quality Manajemen (TQM)". Selain mengurangi kerusakan produk, tujuan pokok kualitas total adalah untuk meningkatkan nilai konsumen. Kualitas produk adalah segala sesuatu yang ditawarkan ke pasar untuk mendapatkan perhatian, dibeli, dipergunakan dan yang dapat memuaskan keinginan atau kebutuhan. Kualitas produk adalah suatu kondisi fisik, sifat, dan fungsi produk, baik itu produk barang atau produk layanan jasa, berdasarkan tingkat mutu yang disesuaikan dengan durabilitas, reliabilitas, serta mudahnya penggunaan, kesesuaian, perbaikan serta komponen lainnya yang dibuat untuk memenuhi kepuasan.

Kualtas produk (product) menurut Kotler (2009) adalah segala sesuatu yang dapat ditawarkan kepasar untuk mendapatkan perhatian, dibeli, digunakan, atau dikonsumsi yang dapat memuaskan keinginan atau kebutuhan. Secara konseptual produk adalah pemahaman subyektif dari produsen atas sesuatu yang bisa ditawarkan sebagai usaha untuk mencapai tujuan organisasi melalui pemenuhan kebutuhan dan kegiatan konsumen, sesuai dengan kompetensi dan kapasitas organisasi serta daya beli pasar. Menurut Kotler dan Keller (2008), produk adalah elemen kunci dalam keseluruhan penawaran pasar. Selain itu produk dapat pula didefinisikan sebagai persepsi konsumen yang dijabarkan oleh produsen melalui hasil produksinya (Tjiptono, 2008). Berdasarkan beberapa definisi diatas, maka produk didefinisikan sebagai kumpulan dari atribut-atribut yang nyata maupun tidak nyata, termasuk di dalamnya kemasan, warna, harga, kualitas dan merek ditambah dengan jasa dan reputasi penjualannya.

Harga merupakan label yang ada dalam sebuah produk yang harus dibayar agar bisa mendapatkan produk atauyang diharapkan jasa. Harga juga menjadi suatu perbandingan dalam menggunakan produk atau jasa. Ini berarti jika harga yang ditentukan sesuai dengan apa yang diharapkan maka konsumen akan merasa puas dalam menggunakan jasa tersebut. Seperti halnya harga dalam proses pemijatan dimana setiap perusahaan di bidang jasa mempunya harga yang bersaing, tetapi konsumen sekarang ini adalah melakukan promosi dan discount yang cukup mengiyurkan konsumennya. Pada saat pandemi saat ini persaingan harga di bidang jasa pastinya sangat ketat maka itu perusahaan senidri di masa pandemi bekerja sama dengan aplikasi traveloka dengan adanya aplikasi traveloka perusahaan sendiri mempunyai banyak keuntungan bagi konsumen dikarenkaan pada aplikasi traveloka banyak sekali promo-promo sehingga membuat daya tarik tersendiri bagi para konsumen dan mudah diakses tanpa harus membawa uang cash. potongan harga yang lainya dari pihak perusahaan sendiri mempunya promo yaitu dalam bentuk member konsumen mendapatkan untung $10 \%$ hingga $15 \%$ dan promo ini sangatlah menarik bagi para konsumen dikarenakan lebih hemat dan lebih bagusnya lagi perusahaan konsumen yang membeli produk bisa dititipkan. Discount dalam segi perbankkan di perusahaan mempunyai promo atau diskon sampai $20 \%$ menggunkan kartu mandiri di konsumen sehingga, dengan adanya banyak promo pada perusahaan membuat para konsumen tertarik.

Iklan adalah pemberitahuan kepada khalayak mengenai barang atau jasa yang dijual, dipasang di dalam media massa (seperti surat kabar dan majalah) atau di tempat umum. Mengiklankan adalah memberitahukan atau memperkenalkan sesuatu kepada umum melalui iklan. Periklanan adalah hal yang berhubungan dengan iklan. Pengiklan adalah orang (perusahaan dan sebagainya) yang mengiklankan; orang (perusahaan dan sebagainya) yang memasang iklan. Atau bagian perusahaan yang mengurus iklan. Iklan biasanya dibuat oleh biro iklan untuk sponsor dan disebarkan melalui berbagai media. Iklan muncul di televisi, radio, surat kabar, majalah, dan papan reklame di jalan-jalan. Iklan telah menjadi salah satu bagian dari industri perdagangan. Perusahaan atau perorangan menawarkan barang atau jasa melalui iklan. Kesimpulannya, iklan adalah pemberitahuan yang bertujuan mendorong atau membujuk khalayak sehingga membeli atau menggunakan barang atau jasa yang diberitahukan.

Pengertian iklan penting diketahui jika kamu bergelut dalam bidang pemasaran dan promosi. Hingga kini iklan menjadi salah satu media paling efektif untuk menjangkau audiens. Ada banyak pengertian iklan yang dikemukakan oleh ahli atau organisasi terkait.Sebelum lebih jauh mengenal dunia perliklanan, ada baiknya memahami pengertian iklan.

Dengan membuat iklan yang menarik, dan menghabiskan dana yang cukup untuk menjangkau banyak pengguna, iklan dapat berdampak langsung pada bisnis. Iklan sangat berguna dalam bidang pemasaran dan promosi. Dalam bisnis, pengertian periklanan adalah untuk menarik pelanggan baru dengan menentukan target pasar dan menjangkau mereka dengan kampanye iklan yang efektif. Periklanan merupakan teknik dan praktik yang digunakan untuk membawa produk, layanan, opini, atau sebab ke perhatian publik dengan tujuan untuk meyakinkan publik agar merespon dengan cara tertentu terhadap apa yang diiklankan. Di banyak 
negara, periklanan merupakan sumber pendapatan terpenting bagi media.

\section{Perumusan Masalah}

Berdasarkan permasalahan seperti yang diuraikan dalam latar belakang masalah, maka perumusan masalah dalam penelitian ini dapat dirumuskan sebagai berikut :

1. Apakah ada pengaruh Kualitas Produk terhadap Kepuasan Pembelian pada PT. Askotama Inti Nusantara?

2. Apakah ada pengaruh Harga terhadap Kepuasan Pembelian pada PT. Askotama Inti Nusantara?

3. Apakah ada pengaruh Iklan terhadap Kepuasan Pembelian pada PT. Askotama Inti Nusantara?

4. Secara simultan apakah ada pengaruh Kualitas Produk, Harha dan Iklan terhadap Kepuasan Pembelian pada PT. Askotama Inti Nusantara?

\section{Tujuan Penelitian}

Berdasarkan pada perumusan masalah tersebut di atas, maka tujuan yang ingin dicapai dalam penelitian ini adalah menjawab perumusan masalah dalam penelitian ini adalah :

1. Untuk mengetahui apakah ada pengaruh Kualitas Produk terhadap Kepuasan Pembelian pada PT. Askotama Inti Nusantara.

2. Untuk mengetahui apakah ada pengaruh Harga terhadap Kepuasan Pembelian pada PT. Askotama Inti Nusantara.

3. Untuk mengetahui apakah ada pengaruh Iklan terhadap Kepuasan Pembelian pada PT. Askotama Inti Nusantara.

4. Secara simultan Untuk mengetahui apakah ada pengaruh Kualitas Produk, Harha dan Iklan terhadap Kepuasan Pembelian pada PT. Askotama Inti Nusantara.

\section{TINJAUAN PUSTAKA}

\section{Pengertian Kualitas Produk}

Menurut Kotler dan Amstrong (2008 : 93) adalah : kualitas adalah karakteristik dari produk dalam kemampuan untuk memenuhi kebutuhan-kebutuhan yang telah ditentukan dan bersifat laten. Sedangkan menurut Garvin dan A. Dale Timpe dalam Alma, (2011 : 92) mengemukakan pengertian kualitas produk bahwa :

"Kualitas adalah keunggulan yang dimiliki oleh produk tersebut. Kualitas dalam pandangan konsumen adalah hal yang mempunyai ruang lingkup tersendiri yang berbeda dengan kualitas dalam pandangan produsen saat mengeluarkan suatu produk yang biasa dikenal kualitas sebenarnya".

Sedangkan menurut Tjiptono (2014:89) mengemukakan pengertian kualitas produk bahwa :

"Kualitas merupakan perpaduan antara sifat dan karakteristik yang menentukan sejauh mana keluaran dapat memenuhi prasyarat kebutuhan pelanggan atau menilai sampai seberapa jauh sifat dan karakteristik itu memenuhi kebutuhannya".

Menurut Kotler and Amstrong (2008 : 98) mengemukakan pengertian kualitas produk adalah :

"The ability of a product to perform its functions, it includes the product's overall durability, reliability, precision, ease of operation and repair, and other valued attributes" yang artinya kemampuan sebuah produk dalam memperagakan fungsinya, hal itu termasuk keseluruhan durabilitas, reliabilitas, ketepatan, kemudahan pengoperasian dan reparasi produk juga atribut produk lainnya".

Berdasarkan penjelasan diatas, maka dapat disimpulkan bahwa kualitas produk adalah keseluruhan barang dan jasa yang berkaitan dengan keinginan konsumer yang secara keunggulan produk sudah layak diperjualkan sesuai harapan dari pelanggan.

Kualitas produk dibentuk oleh beberapa indikator antara lain kemudahan penggunaan, daya tahan, kejelasan fungsi, keragaman ukuran produk, dan lainlain (Zeithalm, 1988 dalam Kotler, 2009). Konsumen senantiasa melakukan penilaian terhadap kinerja suatu produk, hal ini dapat dilihat dari kemampuan produk menciptakan kualitas produk dengan segala spesifikasinya sehingga dapat menarik minat konsumen untuk melakukan pembelian terhadap produk tersebut. Berdasarkan bahasan di atas dapat dikatakan bahwa kualitas yang diberikan suatu produk dapat mempengaruhi keputusan pembelian konsumen terhadap produk yang ditawarkan.

Kualitas produk menurut Kotler dan Amstrong (2009 : 274) mengemukakan pengertian kualitas produk bahwa :

"A quality product as anything that can be offered to a market for attention, acquisition, use or consumption and that might satisfy a want or need". Artinya produk adalah segala sesuatu yang ditawarkan ke pasar untuk mendapatkan perhatian, dibeli, dipergunakan dan yang dapat memuaskan keinginan atau kebutuhan.

Menurut Kotler (2008:408) ada lima tingkatan produk, yaitu core benefit, basic product, expected 
product, augmented product dan potential product. Penjelasan tentang kelima tingkatan produk adalah :

1. Core benefit (namely the fundamental service of benefit that costumer really buying) yaitu manfaat dasar dari suatu produk yag ditawarkan kepada konsumen.

2. Basic product (namely a basic version of the product) yaitu bentuk dasar dari suatu produk yang dapat dirasakan oleh panca indra.

3. Expected product (namely a set of attributes and conditions that the buyers normally expect and agree to when they purchase this product) yaitu serangkaian atribut-atribut produk dan kondisikondisi yang diharapkan oleh pembeli pada saat membeli suatu produk.

4. Augmented product (namely that one includes additional service and benefit that distinguish the company's offer from competitor's offer) yaitu sesuatu yang membedakan antara produk yang ditawarkan oleh badan usaha dengan produk yang ditawarkan oleh pesaing.

5. Potential product (namely all of the argumentations and transformations that this product that ultimately undergo in the future) yaitu semua argumentasi dan perubahan bentuk yang dialami oleh suatu produk dimasa datang.

Berdasarkan definisi-definisi diatas, maka dapat disimpulkan bahwa kualitas merupakan suatu produk dan jasa yang melalui beberapa tahapan proses dengan memperhitungkan nilai suatu produk dan jasa tanpa adanya kekurangan sedikitpun nilai suatu produk dan jasa, dan menghasilkan produk dan jasa sesuai harapan tinggi dari pelanggan.

Untuk mencapai kualitas produk yang diinginkan maka diperlukan suatu standarisasi kualitas. Cara ini dimaksudkan untuk menjaga agar produk yang dihasilkan memenuhi standar yang telah ditetapkan sehingga konsumen tidak akan kehilangan kepercayaan terhadap produk yang bersangkutan. Pemasar yang tidak memperhatikan kualitas produk yang ditawarkan akan menanggung tidak loyalnya konsumen sehingga penjualan produknya pun akan cenderung menurun. Jika pemasar memperhatikan kualitas, bahkan diperkuat dengan periklanan dan harga yang wajar maka konsumen tidak akan berpikir panjang untuk melakukan pembelian terhadap produk.

\section{Pengertian Harga}

Harga merupakan nilai yang diperuntukarkan pelanggan untuk suatu manfaat ataskonsumsi, penggunaan, atau kepemilikan suatu produk dan jasa. Harga memiliki dampal psikologis berupa presepsi kualaitas maupun manfaat emosional. Arti Pentingnya Penetapan Harga. Fandy Tjiptono (2017: 84) mengatakan bahwa :

"Suatu harga yang ditetapkan mempunyai arti yang sangat penting bagi suatu perusahaan terutama untuk menghadapi tingkat persaingan yang semakin ketat serta selera konsumen yang selalu berubah mengikuti perkembangan zaman".

Harga merupakan bauran pemasaran yang bersifat fleksibel artinya diubah dengan cepat. Pentingnya penetapan harga bagi suatu perusahaan adalah sebagai berikut:

a. Harga suatu produk merupakan faktor penentu utama permintaan pasar.

b. Harga mempengaruhi posisi persaingan dan bagian yang mempengaruhi harga saham perusahaan.

c. Harga berpengaruh terhadap kualitas produk. Semakin tinggi harga suatu produk makin tinggi pula kualitas produk tersebut menurut persepsi konsumen.

Menurut Fandy Tjiptono (2017 : 192) mendefinikan pengertian harga bahwa : ". "Harga merupakan satusatunya unsur bauran pemasaran yang memberikan pemasukan atau pendapatan bagi perusahaan dalam menghasilkan laba”.

Berdasarkan definisi di atas bahwa harga ialah sesuatu yang sangat penting untuk kelangsungan hidup perusahaan. Menurut Simamora (2017:77) mendefinikan pengertian harga bahwa :

"Harga merupakan nilai yang diperuntukarkan konsumen untuk suatu manfaat ataskonsumsi, penggunaan, atau kepemilikan suatu produk dan jasa. Harga memiliki dampal psikologis berupa presepsi kualaitas maupun manfaat emosional"

Menurut Kotler dan Keller (2016 : 68) mendefinikan pengertian harga bahwa : "Harga adalah sejumlah uang yang dibebankan atas suatu produk atau jasa, atau jumlah dari nilai uang ditukar konsumen atas manfaat karena memiliki atau menggunakan produk atas jasa tersebut".

Berdasarkan definisi di atas bahwa harga ialah sesuatu yang di bebankan yang ada di dalam produk atau jasa, dimana harga tersebut memiliki manfaat bagi konsumen. Berdasarkan definisi di atas bahwa harga harus mempunyai manfaat dan nilai bagi konsumen yang menggunakan produk atau jasa tersebut. Berdasarkan definisi ahli mengenai harga diatas dapat disimpulkan bahwa harga merupakan nilai yang pertukarkan konsumen untuk suatu manfaat konsumsi suatu produk yang menimbulkan presepsi 
kualitas maupun emosional dimana harga juga menjadi elemen pendapatan bagi perusahaan.

\section{Pengertian Iklan}

Iklan merupakan setiap bentuk komunikasi yang dimaksudkan untuk memotivasi seorang pembeli potensial dan mempromosikan penjual suatu produk Patau jasa, untuk mempengaruhi pendapat publik, memenangkan dukungan publik untuk berpikir atau bertindak sesuai dengan keinginan pemasang iklan. Pengertian iklan:

1. Iklan dapat diartikan sebagai berita pesanan (untuk mendorong, membujuk) kepada khalayak/orang ramai tentang benda atau jasa yang ditawarkan.

2. Iklan dapat pula diartikan sebagai pemberitahuan kepada khalayak/orang ramai mengenai barang atau jasa yang dijual dan dipasang di dalam media massa, seperti surat kabar/koran, majalah dan media elektronik seperti radio, televisi dan internet.

Dari pengertian iklan tersebut dapat disimpulkan bahwa iklan dibuat dengan tujuan untuk menarik perhatian dan mendorong atau membujuk pembaca iklan agar memiliki atau memenuhi permintaan pemasang iklan.

Pada dasarnya iklan merupakan sarana komunikasi yang digunakan komunikator dalam hal ini perusahaan atau produsen untuk menyampaikan informasi tentang barang atau jasa kepada publik, khususnya pelanggannya melalui suatu media massa. Selain itu, semua iklan dibuat dengan tujuan yang sama yaitu untuk memberi informasi dan membujuk para konsumen untuk mencoba atau mengikuti apa yang ada di iklan tersebut, dapat berupa aktivitas mengkonsumsi produk dan jasa yang ditawarkan. Jika dilihat dari artinya iklan berbeda dengan periklanan, dimana iklan adalah sebagai pesan yang disampaikan kepada konsumen baik secara lisan atau dalam penglihatan.

Tujuan periklanan menurut Kotler dan Armstrong (2008 :151), dalam buku prinsip-prinsip pemasaran adalah tugas komunikasi spesifik yang dicapai dengan pemirsa sasaran tertentu selama periode waktu tertentu, dan selanjutnya akan dijelaskan fungsi-fungsi dari periklanan.

Fungsi-Fungsi periklanan definisi hanya memberikan sebuah bahasa umum untuk mengembangkan pemahaman tentang periklanan. Efek periklanan pada sebuah organisasi bisa jadi dramatik dan juga perlu di eksplorasi. Berikut fungsifungsi dari periklanan menurut Monle Lee dan Carla Johnson (2004:10) mengemukakan bahwa :
1. Periklanan menjalankan sebuah fungsi "informasi", yang mengomunikasikan informasi produk, ciri-ciri, dan lokasi penjualannya, yang memberitahu konsumen tentang produkproduk baru.

2. Periklanan menjalankan sebuah fungsi "persuasif", yang mencoba membujuk para konsumen untuk membeli merek-merek tertentuatau mengubah sikap mereka terhadap produk atau perusahaan tersebut.

3. Periklanan menjalankan sebuah fungsi "pengingat", yang terusmenerus mengingatkan para konsumen tentang sebuah produk sehingga mereka akan tetap membeli produk yang diiklankan tanpa mempedulikan merek pesaingnya.

Kegiatan-kegiatan periklanan memang bisa menelan biaya yang sangat mahal, namun selama itu didasarkan pada tujuan dan perhitungan yang serba jelas semuanya bisa dibenarkan. Yang penting, semua kegiatan itu tetap efektif dan ekonomis, dalam pengertian dapat mencapai sasaran dan tetap menjamin keuntungan perusahaan. sebuah periklanan baru bisa dikatakan baik jika semuanya terencana dan terselenggara sedemikian rupa sehingga dapat mencapai hasil-hasil yang diharapkan.

\section{Pengertian Kepuasan Pembelian}

Tercapainya tujuan perusahaan ditandai oleh jumlah konsumen yang melakukan pembelian atau transaksi terhadap produk sehingga kebutuhan produk tersebut merupakan pengarahan dari perilaku konsumen. Salah satu proses dari perilaku konsumen yaitu keputusan pembelian. Konsumen dihadapkan berbagai pilihan alternatif sehingga konsumen akan memutuskan untuk membeli produk berdasarkan pilihan yang ditentukan. Menurut Buchari Alma (2013: 96) mengemukakan pengeertian keputusan pembelian bahwa :

"Keputusan pembelian adalah suatu keputusan konsumen yang dipengaruhi oleh ekonomi keuangan, teknologi, politik, budaya, produk, harga, lokasi, promosi, physical evidence, people dan process sehingga membentuk suatu sikap pada konsumen untuk mengolah segala informasi dan mengambil kesimpulan berupa respon yang muncul produk apa yang dibeli.

Menurut Kotler dan Amstrong (2016: 177) mendefinisikan keputusan pembelian bahwa :

"Keputusan pembelian merupakan bagian dari perilaku konsumen yaitu studi tentang bagaimana individu, kelompok, dan organisasi memilih, membeli, 
menggunakan dan bagaimana barang, jasa, ide atau pengalaman untuk memuaskan kebutuhan dan keinginan mereka".

Selain itu Machfoedz (2013: 44) mengemukakan keputusan pembelian bahwa : Keputusan pembelian adalah suatu proses penilaian dan pemilihan dari berbagai alternatif sesuai dengan kepentingankepentingan tertentu dengan menetapkan suatu pilihan yang dianggap paling menguntungkan".

Dari beberapa definisi para ahli, penulis dapat menyimpulkan bahwa keputusan pembelian adalah salah satu konsep dari perilaku konsumen baik individu, kelompok ataupun organisasi yang menetapkan suatu pilihan yang dianggap memuaskan atau menguntungkan. Keputusan pembelian muncul karena adanya dorongan emosional dari dalam diri maupun pengaruh dari luar. Proses keputusan pembelian merupakan proses psikologi dasar yang memainkan peranan penting dalam memahami bagaimana konsumen benar-benar membuat keputusan pembelian mereka. Menurut Kotler dan Amstrong (2016:176) terdapat lima model yang mempengaruhi proses keputusan pembelian berikut uraiannya :

1. Pengenalan masalah Proses pembelian dimulai ketika pembeli menyadari suatu masalah atau kebutuhan yang dipicu oleh rangsangan internal atau eksternal.

2. Pencarian informasi Sumber informasi utama konsumen dibagi menjadi empat kelompok :

a. Pribadi. Keluarga, teman, tetangga, rekan.

b. Komersial. Iklan, situs web, wiraniaga, penyalur, kemasan, tampilan

c. Publik. Media massa, organisasi pemeringkat konsumen.

d. Ekperimental. Penanganan, pemeriksaan, penggunaan produk

Keputusan merupakan suatu pemecahan masalah sebagai suatu hukum situasi yang dilakukan melalui pemilihan satu alternatif dari beberapa alternatif. Menurut Ujang Samarwan pembelian adalah keputusan konsumen mengenai apa yang dibeli, apakah membeli atau tidak, kapan membeli, dimana membeli, dan bagaimana cara membayarnya.

Menurut Schiffman, Kanuk dalam jurnal Hatane Samuel pengambilan keputusan pembelian adalah pemilihan dari dua atau lebih alternatif pilihan keputusan pembelian, artinya bahawa seseorang dapat membuat keputusan haruslah tersedia beberapa alternatif pilihan. Keputusan untuk membeli dapat mengarah kepada bagaimana proses dalam pengambilan keputusan tersebut dilakukan. Model sederhana dari pengambilan keputusan pembelian menurut Schiffman dan Kanuk (2009 : 443) terdiri dari 3 komponen, yaitu input, proses dan output, sebagaimana disajikan pada gambar di bawah ini :

\section{Gambar 1}

Model Sederhana Pengambilan Keputusan Pembelian

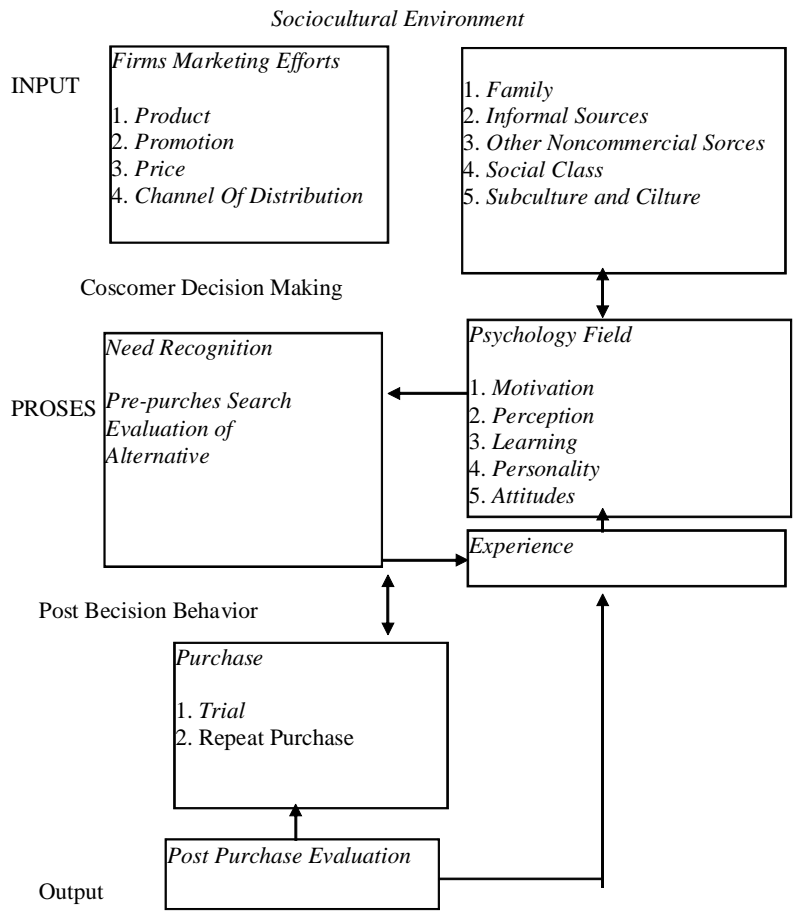

Sumber : Schiffman, Leon G..; Kanuk Leslie Lazar. 2000. Costumer Bahavior. Seven Edition, Prentice Hall International, inc. Upper Saddle River. New Jersey. (hal 443).

Pengambilan keputusan pembelian adalah proses pengintegrasian yang mengkombinasikan pengetahuan untuk mengevaluasi dua atau lebih perilaku alternatif dan memilih satu diantaranya. Gambar 2

Pengambilan Keputusan Pembelian

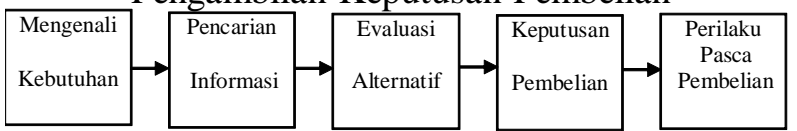

Penjelasan :

1. Pengenalan Masalah

Proses pembelian dimulai saat pembeli mengenali sebuah masalah atau kebutuhan, sehingga kebutuhan tersebut mendorong minat konsumen untuk melakukan pembelian.

2. Pencarian Informasi Setelah menganalisis masalah- masalah yang dihadapi, konsumen akan mencari informasi lebih lanjut mengenai 
barang yang dibutuhkan. Jika dorongan dari diri konsumen kuat maka proses pembelian akan dilakukannya, tetapi jika tidak maka keinginan tersebut akan disimpan dalam ingatannya. Kotler berpendapat sumber informasi konsumen digolongkan kedalam empat kelompok:

a. Sumber Pribadi : Keluarga, teman, tetangga, kenalan

b. Sumber Komersial : Iklan, Pajangan di toko, Kemasan, Penyalur

c. Sumber Publik: Media massa, Organisasi penentu peringkat konsumen.

d. Sumber Pengalaman : Penanganan, Pengkajian, dan Pemakaian Produk.

3. Evaluasi Alternatif Setelah dilakukan pencarian informasi mengenai barang yang dibutuhkan maka konsumen akan mengidentifkasi dan mengevaluasi cara-cara untuk memenuhi kebutuhan dirinya maupun organisasinya, mencari pilihan yang terbaik menyangkut kualitas, harga, waktu, pengiriman, dan faktorfaktor lain yang dianggap penting. Dalam tahap ini seruan-seruan periklanan yang rasioanal dan emosional memainkan peran penting.

4. Keputusan Pembelian Dalam melaksanakan niat pembelian konsumen dapat membuat suatu keputusan pembelian: keputusan merek, pemasok, kuantitas, waktu, metode pembayaran.

5. Perilaku Pasca Pembayaran Setelah membeli produk, konsumen akan mengalami level kepuasan atau ketidakpuasan tertentu. Dan para pemasar harus memantau kepuasan pasca pembelian, tindakan pasca pembelian, dan pemakaian produk pasca pembelian. Philip Kotler, Gary Armstrong, Prinsip-prinsip Pemasaran, (Jakarta: Erlangga, 2008)

\section{METODE PENELITIAN}

\section{Populasi}

Populasi adalah jumlah keseluruhan orang yang akan diteliti. Menurut pendapat Hadari Nawawi (2012 : 141) mengatakan bahwa :

"Populasi adalah keseluruhan obyek penelitian yang dapat terdiri dari manusia, benda-benda hewan, tumbuh-tumbuhan, gejala-gejala, nilai test atau peristiwa-peristiwa sebagai sumber data yang memilii karekteristik tertentu dalam penelitian".

Sedangkan menurut pendapat Sugiyono (2016 : 57), mengemukakan pengertian populasi bahwa :

"Populasi adalah merupakan suatu wilayah generalisasi yang terdiri atas : obyek/subyek yang mempunyai kualitas dan karateristik tertentu yang ditetapkan oleh peneliti untuk dipelajari dan kemudian ditarik kesimpulannya".

Populasinya adalah 200 orang dari perusahaan sebagai Pembelian pada PT. Askotama Inti Nusantara.

\section{Sampel}

Teknik pengambilan sampel yang dipakai dalam penelitian ini penulis menggunakan teknik Random Sampling atau secara acak. Dimana setiap populasi mempunyai peluang yang sama untuk dipilih sebagai sampel. Ukuran sampel penulis menggunakan teori atau menurut Suharsimi Arikunto, (2008 : 95) mengemukakan bahwa :

"Sebagai ancer-ancer, jika peneliti mempunyai beberapa ratus subjek dalam populasi mereka dapat menggunakan kurang lebih 25-30\% dari jumlah tersebut, jika anggota subjek dalam populasi hanya meliputi antara 100 hingga 150 orang, dan dalam pengumpulan data peneliti menggunakan angket, sebaiknya subjek dalam populasi diambil seluruhnya.

Jadi teknik pengambilan sampel yang dipakai dalam penelitian ini penulis menggunakan teknik penelitian teknik random Sampling atau secara acak sejumlah $25 \%$ atau 50 orang sampel dari 200 orang populasi. Adapun jumlah populasi dan sampel dalam penelitian.

\section{Instrumen/Alat Pengumpulan Data}

Menurut Suharsimi Arikunto (2014: 225), Teknik pengumpulan data merupakan suatu usaha sadar untuk mengumpulkan data yang dilaksanakan secara sistematis dengan prosedur yang standar. Teknik pengumpulan data yang digunakan dalam penelitian ini adalah: Kuesioner (Angket).

Kuesioner adalah sejumlah pertanyaan tertulis yang digunakan untuk memperoleh informasi dari responden dalam arti laporan tentang pribadinya atau hal-hal yang diketahui. Menurut Suharsimi Arikunto (2014 : 140) Metode ini digunakan untuk mengumpulkan data dari responden mengenai Loyalitas, Harga dan Kepuasan Pembelian. Menurut Sonny Harsono (2010 : 290) mengemukakan pengertian kuesioner adalah :

"Kuesioner yaitu suatu teknik pengumpulan data dengan menggunakan seperangkat pertanyaan yang disusun untuk diajukan kepada para karyawan. Kuesioner ini dimaksudkan untuk memperoleh data secara tertulis dari para karyawan untuk ditetapkan sebagai sampel". 
Jenis instrumen yang digunakan dalam penelitian ini berupa skala yaitu merupakan kumpulan dari pernyataan atau pertanyaan yang pengisiannya oleh responden dilakukan dengan memberikan tanda centang (") pada tempat yang sudah disediakan dengan alternatif jawaban yang disediakan merupakan sesuatu yang berjenjang.

Untuk mengetahui distribusi frekuensi masingmasing variabel yang pengumpulan datanya menggunakan keusioner (angket), setiap indikator dari data yang dikumpulkan terlebih dahulu diklasifikasikan dan diberi skor atau nilai yaitu:

Tabel 1

Pilihan Jawaban

\begin{tabular}{|c|l|c|c|}
\hline No. & \multicolumn{1}{|c|}{ Jawabannya } & Disingkat & Bobot \\
\hline 1 & Sangat Tidak Setuju & STS & 1 \\
\hline 2 & Tidak Setuju & TS & 2 \\
\hline 3 & Cukup Setuju & CS & 3 \\
\hline 4 & Setuju & S & 4 \\
\hline 5 & Sangat Setuju & SS & 5 \\
\hline
\end{tabular}

Sumber : Sugiyono, 2016.

\section{Tehnik Analisis Data}

Uji Validitas, Adapun teknik korelasi yang diterapkan dalam penelitian ini adalah teknik product moment correlation. Adapun rumus korelasi Product Moment menurut Sugiyono, (2016 : 182), untuk mencari nilai $\mathrm{r}_{\text {hitung }}$ atau validitas sebagai berikut:

$$
\mathbf{r}_{\mathrm{xy}}=\frac{n \cdot \Sigma X Y-\Sigma X \cdot \Sigma Y}{\sqrt{n\left(\Sigma X^{2}\right)-(\Sigma X)^{2}} \cdot \sqrt{n \cdot\left(\Sigma Y^{2}\right)-(\Sigma Y)^{2}}}
$$

\section{Dimana :}

$$
\begin{aligned}
\mathrm{r}_{\mathrm{xy}} & =\text { Koefisien Korelasi antara } \mathrm{X} \text { dan } \mathrm{Y} \\
\sum \mathrm{XY} & =\text { Jumlah perkalian antara } \mathrm{X} \text { dan } \mathrm{Y} \\
\sum \mathrm{X}^{2} & =\text { Jumlah kuadrat } \mathrm{X} \\
\sum \mathrm{Y}^{2} & =\text { Jumlah kuadrat } \mathrm{Y} \\
\mathrm{n} & =\text { Jumlah Sampel (Banyaknya Data). }
\end{aligned}
$$

Item-item pertanyaan di dalam angket dikatakan valid apabila nilai $r_{\text {hitung }}>$ dari $r_{\text {tabel }}$, sedangkan apabila nilai $r_{\text {hitung }}<$ dari $r_{\text {tabel }}$ maka item-item pertanyaan di dalam angket dikatakan tidak valid (Sugiyono, 2016:182).

Uji Reliabilitas, diukur dengan menggunakan metode cronbach alpha. Rumus Cronbach alpha: Adapun rumus untuk mencari nilai reliabilitas menurut Sugiyono, (2016:122) sebagai berikut :

$$
\mathrm{r}_{11}=\left[\frac{k}{k-1}\right]\left[1 \frac{\sum a_{b}^{2}}{a_{t}^{2}}\right]
$$

\section{Keterangan :}

$\mathrm{r}_{11}=$ reliabilitas instrumen

$\mathrm{k}=$ banyaknya butir pertanyaan atau banyaknya soal

$\sum \alpha_{\mathrm{b}}^{2}=$ jumlah varianes butir

$\alpha_{\mathrm{t}}^{2}=$ varians total.

Suatu kuesioner dinyatakan reliabel apabila nilai $r_{\text {hitung }}$ lebih besar daripada nilai $r_{\text {tabel }}$ dengan taraf signifikan $5 \%$.

a. Uji t

Uji t dilakukan untuk mengetahui pengaruh signifikan secara parsial antara variabel independen terhadap variabel dependen. Nilai t test dapat diketahui dari nilai sig pada tabel Coefficientsa dalam output regression SPSS Versi 24 for windows.

\section{b. Uji F}

Uji $\mathrm{F}$ dilakukan untuk mengetahui pengaruh signifikan secara simultan antara Kualaitas Produk, Harga dan Iklan terhadap Kepuasan Pembelian. Nilai F test dapat diketahui dari nilai sig pada tabel anovab dalam output regression SPSS Versi 24 for windows.

\section{ANALISA DAN PEMBAHASAN}

Uji Validitas dan Reliabilitas Data Hasil Angket a. Variabel Kualitas Produk $\left(\mathbf{X}_{1}\right)$

Untuk dapat mengetahui hasil analisis variabel Kualitas Produk $\left(\mathrm{X}_{1}\right)$ menggunakan Komputer program Statistical Package for Social Sciences (SPSS) Versi 24 for Windows, data variabel Kualitas Produk $\left(\mathrm{X}_{1}\right)$ yang merupakan data ordinal dari sampel berjumlah 10 Try Out $(\mathrm{N}=10)$ dengan jumlah soal ada 10 pertanyaan adalah :

Tabel 2

PERBANDINGAN HASIL $r_{\text {hitung }}$ dengan $r_{\text {tabel }}$ VARIABEL KUALITAS PRODUK $\left(\mathrm{X}_{1}\right)$ Pertanyaan KUALITAS PRODUK $\left(\mathrm{X}_{1}\right)$

\begin{tabular}{|c|c|c|c|}
\hline \multirow{2}{*}{ Pertanyaan } & \multicolumn{3}{|c|}{ KUALITAS PRODUK $\left(\mathbf{X}_{\mathbf{1}}\right)$} \\
\cline { 2 - 4 } & $\mathbf{r}_{\text {hitung }}$ & $\mathbf{r}_{\text {tabel }}$ & Keterangan \\
\hline 1 & 0,708 & 0,666 & Valid \\
2 & 0,749 & 0,666 & Valid \\
3 & 0,703 & 0,666 & Valid \\
4 & 0,685 & 0,666 & Valid \\
5 & 0,764 & 0,666 & Valid \\
6 & 0,833 & 0,666 & Valid \\
7 & 0,789 & 0,666 & Valid \\
8 & 0,909 & 0,666 & Valid \\
9 & 0,886 & 0,666 & Valid \\
10 & 0,853 & 0,666 & Valid \\
\hline
\end{tabular}


Uji Reliabilitas variabel Kualitas Produk $\left(\mathrm{X}_{1}\right)$ dengan nilai $r_{\text {tabel }} 0,666$ sedangkan nilai Alpha 0,944 sehingga dapat disimpulkan bahwa Alpha positif dan lebih besar atau 0,944>0,666 maka instrumen penelitian variabel Kualitas Produk $\left(\mathrm{X}_{1}\right)$ adalah Reliabel. Untuk lebih jelas lihat tabel berikut ini. Tabel 3

\section{UJI RELIABILITAS VARIABEL KUALITAS PRODUK $\left(\mathrm{X}_{1}\right)$}

Reliability Statistics

\begin{tabular}{|r|c|}
\hline \multicolumn{2}{|c|}{$\begin{array}{c}\text { Cronbach's } \\
\text { Alpha }\end{array}$} \\
\hline$\quad 944$ & N of Items \\
\hline
\end{tabular}

Sumber : Sumber Data diolah SPSS

\section{b. Variabel Harga $\left(X_{2}\right)$}

Untuk mengetahui hasil analisis variabel Harga $\left(\mathrm{X}_{2}\right)$ dengan menggunakan Komputer program Statistical Package for Social Sciences (SPSS) Versi 24 for Windows input data variabel Harga $\left(\mathrm{X}_{2}\right)$ yang merupakan data ordinal dari sampel berjumlah 10 Try Out $(\mathrm{N}=10)$ dengan soal ada 10 pertanyaan, sebagai berikut :

Tabel 4

PERBANDINGAN HASIL $r_{\text {hitung }}$ dengan $r_{\text {tabel }}$ VARIABEL HARGA $\left(\mathrm{X}_{2}\right)$

\begin{tabular}{|c|c|c|c|}
\hline \multirow{2}{*}{ Pertanyaan } & \multicolumn{3}{|c|}{ HARGA $\left(\mathbf{X}_{2}\right)$} \\
\cline { 2 - 4 } & $\mathbf{r}_{\text {hitung }}$ & $\mathbf{r}_{\text {tabel }}$ & Keterangan \\
\hline 1 & 0,775 & 0,666 & Valid \\
2 & 0,828 & 0,666 & Valid \\
3 & 0,909 & 0,666 & Valid \\
4 & 0,806 & 0,666 & Valid \\
5 & 0,835 & 0,666 & Valid \\
6 & 0,708 & 0,666 & Valid \\
7 & 0,797 & 0,666 & Valid \\
8 & 0,715 & 0,666 & Valid \\
9 & 0,784 & 0,666 & Valid \\
10 & 0,786 & 0,666 & Valid \\
\hline
\end{tabular}

Sumber : Sumber Data diolah SPSS

Uji Reliabilitas variabel Harga $\left(\mathrm{X}_{2}\right)$ dengan Nilai $\mathrm{r}_{\text {tabel }}$ 0,666 sedangkan nilai Alpha 0,948 sehingga dapat disimpulkan bahwa Alpha positif dan lebih besar atau $0,948>0,666$ maka instrumen variabel Harga $\left(X_{2}\right)$ adalah Reliabel. Untuk lebih jelas dapat dilihat pada tabel berikut ini.

Tabel 5

UJI RELLIABILITAS VARIABEL HARGA (X^)

Reliability Statistics

\begin{tabular}{|c|c|}
\hline $\begin{array}{l}\text { Cronbach's } \\
\text { Alpha }\end{array}$ & $\mathrm{N}$ of Items \\
\hline ,948 & 10 \\
\hline
\end{tabular}

\section{c. Variabel Iklan $\left(\mathbf{X}_{3}\right)$}

Untuk mengetahui hasil analisis variabel Iklan $\left(\mathrm{X}_{3}\right)$ dengan menggunakan Komputer program Statistical Package for Social Sciences (SPSS) Versi 24 for Windows input data variabel Iklan $\left(\mathrm{X}_{3}\right)$ yang merupakan data ordinal dari sampel berjumlah 10 Try Out $(\mathrm{N}=10)$ dengan soal ada 10 pertanyaan, sebagai berikut :

Tabel 6

PERBANDINGAN HASIL $r_{\text {hitung }}$ dengan $r_{\text {tabel }}$ VARIABELIKLAN $\left(\mathrm{X}_{2}\right)$

\begin{tabular}{|c|c|c|c|}
\hline \multirow{2}{*}{ Pertanyaan } & \multicolumn{3}{|c|}{ IKLAN $\left(\mathbf{X}_{\mathbf{2}}\right)$} \\
\cline { 2 - 4 } & $\mathbf{r}_{\text {hitung }}$ & $\mathbf{r}_{\text {tabel }}$ & Keterangan \\
\hline 1 & 0,681 & 0,666 & Valid \\
2 & 0,682 & 0,666 & Valid \\
3 & 0,886 & 0,666 & Valid \\
4 & 0,716 & 0,666 & Valid \\
5 & 0,735 & 0,666 & Valid \\
6 & 0,738 & 0,666 & Valid \\
7 & 0,849 & 0,666 & Valid \\
8 & 0,671 & 0,666 & Valid \\
9 & 0,723 & 0,666 & Valid \\
10 & 0,951 & 0,666 & Valid \\
\hline
\end{tabular}

Sumber : Sumber Data diolah SPSS

Uji Reliabilitas variabel Iklan $\left(\mathrm{X}_{3}\right)$ dengan Nilai $r_{\text {tabel }}$ 0,666 sedangkan nilai Alpha 0,937 sehingga dapat disimpulkan bahwa Alpha positif dan lebih besar atau $0,937>0,666$ maka instrumen variabel Iklan $\left(\mathrm{X}_{3}\right)$ adalah Reliabel. Untuk lebih jelas dapat dilihat pada tabel berikut ini.

Tabel 7

IIII RFI I I R RII ITAS VARIARFI IKI $\Delta$ N (X) Reliability Statistics

\begin{tabular}{|r|rc|}
\hline \multicolumn{2}{|c|}{$\begin{array}{c}\text { Cronbach's } \\
\text { Alpha }\end{array}$} & \multicolumn{2}{|c|}{ N of Items } \\
\hline &, 937 & \\
\hline
\end{tabular}

Sumber : Sumber Data diolah SPSS

\section{d. Variabel Kepuasan Pembelian (Y)}

Untuk mengetahui hasil analisis dari variabel Kepuasan Pembelian (Y) menggunakan Komputer program Statistical Package for Social Sciences (SPSS) Versi 24 for Windows input data variabel Kepuasan Pembelian yang merupakan data ordinal dari sampel berjumlah 10 Try Out $(\mathrm{N}=10)$ dengan soal ada 10 pertanyaan sebagai berikut : 
Tabel 8

PERBANDINGAN HASIL $r_{\text {hitung }}$ dengan $r_{\text {tabel }}$ VARIABEL KEPUASAN PEMBELIAN (Y)

\begin{tabular}{|c|c|c|c|}
\hline \multirow{2}{*}{ Pertanyaan } & \multicolumn{3}{|c|}{ KEPUASAN PEMBELIAN (Y) } \\
\cline { 2 - 4 } & $\mathbf{r}_{\text {hitung }}$ & $\mathbf{r}_{\text {tabel }}$ & Keterangan \\
\hline 1 & 0.940 & 0,666 & Valid \\
2 & 0.725 & 0,666 & Valid \\
3 & 0.722 & 0,666 & Valid \\
4 & 0.761 & 0,666 & Valid \\
5 & 0.984 & 0,666 & Valid \\
6 & 0.716 & 0,666 & Valid \\
7 & 0.753 & 0,666 & Valid \\
8 & 0.884 & 0,666 & Valid \\
9 & 0.986 & 0,666 & Valid \\
10 & 0.860 & 0,666 & Valid \\
\hline
\end{tabular}

Sumber : Sumber Data diolah SPSS

Uji Reliabilitas variabel Kepuasan Pembelian (Y) dengan nilai $r_{\text {tabel }} 0,666$, sedangkan pada nilai Alpha sebesar 0,976 sehingga dapat disimpulkan bahwa $\mathrm{r}_{\text {Alpha }}$ positif dan lebih besar atau 0,976>0,666 maka dengan demikian instrumen penelitian variabel Kepuasan Pembelian (Y) adalah Reliabel. Untuk jelas lihat tabel berikut ini.

Tabel 9

Uji Relliabilitas

VARIABEL KEPUASAN PEMBELIAN (Y) Reliability Statistics

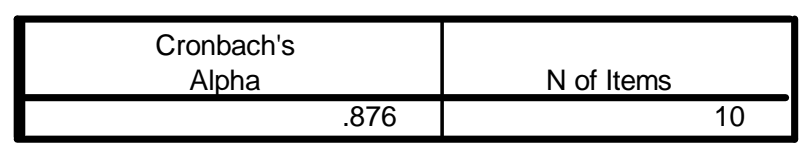

Sumber : Sumber Data diolah SPSS

\section{Analisis Koefisien Korelasi Parsial}

Hasil Analisis Korelasi Pasrial adalah salah satu metode statistik yang digunakan untuk mengetahui tingkat atau besarnya Pengaruh Variabel Kualitas Produk $\left(\mathrm{X}_{1}\right)$, dan Harga $\left(\mathrm{X}_{2}\right)$ terhadap variabel Kepuasan Pembelian (Y) dapat dilihat pada tabel 8 berikut ini.

Tabel 10

HASIL ANALISIS KORELASI PARSIAL

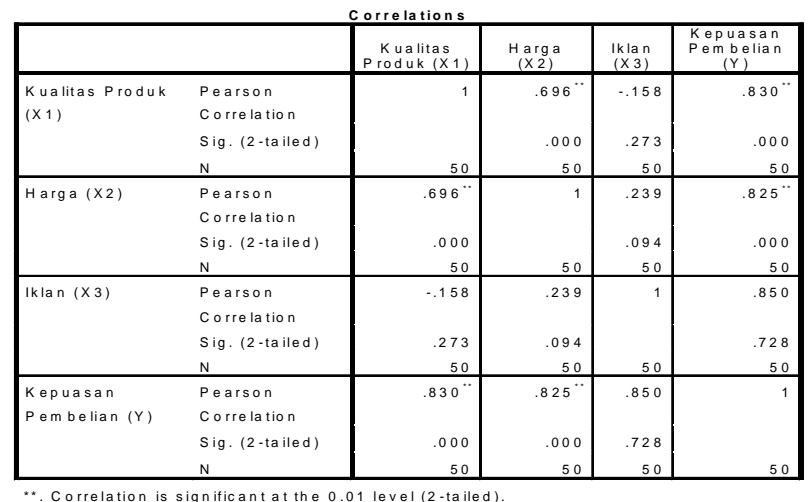

Sumber : Sumber Data diolah SPSS

\section{Koefisien Korelasi Berganda}

Tujuan analisis koefisien korelasi dimasud untuk mengetahui tingkat pengaruh dan signifikan pengaruh antara variabel independen yakni variabel dengan variabel dependen yakni variabel baik secara simultan (bersama-sama) dengan menggunakan komputer program Statistical Package for Social Sciences (SPSS) Versi 24 for Windows adapun hasilnya lihat tabel model Summary sebagai berikut :

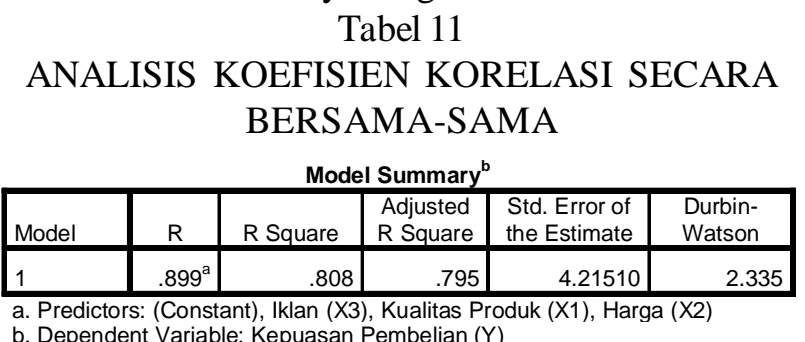

b. Dependent Variable: Kepuasan Pembelian $(Y)$

\section{Sumber : Sumber Data diolah SPSS}

\section{Analisis Regresi Linear Berganda}

Hasil analisis regresi linear berganda dengan menggunakan Komputer program Statistical Package for Social Sciences (SPSS) Versi 24 for Windows yakni diperoleh nilai adalah sebagai berikut:

Tabel 12

ANALISIS REGRESI LINEAR BERGANDA

\begin{tabular}{|c|c|c|c|c|c|c|}
\hline \multicolumn{7}{|c|}{ Coefficients $^{a}$} \\
\hline \multirow[b]{2}{*}{ Mode } & & \multicolumn{2}{|c|}{$\begin{array}{l}\text { Unstandardized } \\
\text { Coefficients }\end{array}$} & $\begin{array}{c}\text { Standardized } \\
\text { Coefficients }\end{array}$ & \multirow[b]{2}{*}{$t$} & \multirow[b]{2}{*}{ Sig. } \\
\hline & & $\mathrm{B}$ & Std. Error & Beta & & \\
\hline 1 & (Constant) & 8.869 & 5.637 & & 1.573 & .123 \\
\hline & Kualitas Produk (X1) & .441 & .088 & .508 & 4.994 & .000 \\
\hline & Harga (X2) & .444 & .098 & .467 & 4.511 & .000 \\
\hline & Iklan (X3) & .531 & .123 & .019 & 5.633 & .000 \\
\hline
\end{tabular}

a. Dependent Variable: Kepuasan Pembelian $(\mathrm{Y})$

Sumber : Sumber Data diolah SPSS

Untuk menentukan nilai persamaan regresi linear bergandanya sebagai berikut :

$$
\mathrm{Y}=8,869+0.441 \mathrm{X}_{1}+0,444 \mathrm{X}_{2}+0.531 \mathrm{X}_{3}
$$

Dapat dijelaskan sebagai berikut :

a. Nilai konstanta intersep sebesar 8,869 menyatakan bahwa jika variabel Kualitas Produk $\left(\mathrm{X}_{1}\right)$ variabel Harga $\left(\mathrm{X}_{2}\right)$ Iklan $\left(\mathrm{X}_{3}\right)$ meningkat I satuan, maka variabel Kepuasan Pembelian (Y) akan meningkat sebesar 8,869 hal ini menggambarkan Kepuasan Pembelian (Y) rata-rata jika Kualitas Produk $\left(\mathrm{X}_{1}\right)$ dan Harga $\left(X_{2}\right)$, Iklan $\left(X_{3}\right)$ nilainya nol.

b. Nilai koefisen regresi variabel Kualitas Produk $\left(\mathrm{X}_{1}\right)$ terhadap Kepuasan Pembelian (Y) adalah sebesar 0,441. Hal ini berarti jika variabel Kualitas Produk $\left(\mathrm{X}_{1}\right)$ naik 1 satuan akan 
meningkatkan variabel Kepuasan Pembelian (Y) sebesar 0,441, dengan asumsi variabel Kualitas Produk $\left(\mathrm{X}_{1}\right)$ dan variabel Harga $\left(\mathrm{X}_{2}\right)$ dianggap konstan.

c. Nilai koefisien regresi variabel Harga $\left(\mathrm{X}_{2}\right)$ terhadap variabel Kepuasan Pembelian (Y) adalah sebesar 0,444 . Hal ini berarti jika variabel Harga $\left(X_{2}\right)$ meningkat 1 satuan maka variabel Kepuasan Pembelian (Y) akan meningkat sebesar 0,444 dengan asumsi variabel Harga $\left(\mathrm{X}_{2}\right)$, dan variabel Kualitas Produk $\left(\mathrm{X}_{1}\right)$ dianggap konstan.

d. Nilai koefisien regresi variabel Iklan $\left(\mathrm{X}_{3}\right)$ terhadap variabel Kepuasan Pembelian (Y) adalah sebesar 0,531 . Hal ini berarti jika variabel Iklan $\left(\mathrm{X}_{2}\right)$ meningkat 1 satuan maka variabel Kepuasan Pembelian (Y) akan meningkat sebesar 0,531 dengan asumsi variabel Iklan $\left(\mathrm{X}_{3}\right)$, Harga $\left(X_{2}\right)$ dan variabel Kualitas Produk $\left(X_{1}\right)$ dianggap konstan.

\section{Uji t}

Untuk mengetahui apakah masing-masing variabel penelitian ini diantaranya adalah Kualitas Produk $\left(X_{1}\right)$ dan variabel Harga $\left(X_{2}\right)$ secara parsial mempunyai pengaruh bermakna terhadap variabel Kepuasan Pembelian (Y) dilakukan pengujian $t_{\text {hitung }}$ dan $t_{\text {tabel }}$. Untuk Uji t ini penulis melakukan dengan cara membandingkan antara $t_{\text {hitung }}$ dengan $t_{\text {tabel }}$ yaitu memiliki nilai masing-masing sebagai berikut Tabel 13

Hasil Uji t (Hipotesis)

\begin{tabular}{|l|c|c|c|c|}
\hline \multicolumn{1}{|c|}{ Variabel } & Nilai & $\begin{array}{c}\text { Standard } \\
\text { Error }\end{array}$ & $\mathbf{t}_{\text {hitung }}$ & $\mathbf{t}_{\text {tabel }}$ \\
\hline Kualitas Produk $\left(\mathrm{X}_{1}\right)$ & 0,441 & 0,088 & 4,994 & 1,682 \\
\hline Harga $\left(\mathrm{X}_{2}\right)$ & 0,444 & 0,095 & 4,511 & 1,682 \\
\hline Iklan $\left(\mathrm{X}_{3}\right)$ & 0,531 & 0,123 & 5,633 & 1,682 \\
\hline
\end{tabular}

Sumber : Sumber Data diolah SPSS

Berdasarkan hasil uji hipotesis antara variabel Kualitas Produk $\left(\mathrm{X}_{1}\right)$ Terhadap Kepuasan Pembelian (Y) diperoleh nilai $\mathrm{t}_{\text {hitung }}$ sebesar $=4,994>\mathrm{t}_{0,05(48)}=$ 1,682, maka $\mathrm{H}_{\mathrm{o}}$ ditolak dan $\mathrm{H}_{\mathrm{a}}$ diterima yang berarti mempunyai cukup bukti bahwa antara variabel Kualitas Produk $\left(\mathrm{X}_{1}\right)$ terhadap variabel Kepuasan Pembelian (Y) ada pengaruh signifikan.

Dari hasil uji hipotesis antara variabel Harga $\left(\mathrm{X}_{2}\right)$ terhadap Kepuasan Pembelian (Y) diperoleh nilai $\mathrm{t}_{\text {hitung }}=4,511>\mathrm{t}_{0,05(48)}=1,682$, maka $\mathrm{H}_{\mathrm{o}}$ ditolak dan $\mathrm{H}_{\mathrm{a}}$ diterima yang berarti mempunyai bukti, bahwa antara variabel Harga $\left(\mathrm{X}_{2}\right)$ terhadap Kepuasan Pembelian (Y) ada pengaruh signifikan.
Dari hasil uji hipotesis antara variabel Iklan $\left(\mathrm{X}_{3}\right.$ terhadap Kepuasan Pembelian (Y) diperoleh nilai $\mathrm{t}_{\text {hitung }}=5,633>\mathrm{t}_{0,05(48)}=1,682$, maka $\mathrm{H}_{\mathrm{o}}$ ditolak dan $\mathrm{H}_{\mathrm{a}}$ diterima yang berarti mempunyai bukti, bahwa antara variabel Harga $\left(X_{2}\right)$ terhadap Kepuasan Pembelian (Y) ada pengaruh signifikan.

\section{Uji F (Anova)}

Untuk mengetahui hasil uji $\mathrm{F}_{\text {hitung }}$ (Anova) dengan menggunakan Komputer program Statistical Package for Social Sciences (SPSS) Versi 24 for windows yakni uji ANOVA, Untuk lebih jelas dapat dilihat pada tabel 14 berikut ini.

\section{Tabel 14}

HASIL UJI F SECARA SIMULTAN (BERSAMA-SAMA)

\begin{tabular}{|c|c|c|c|c|c|c|}
\hline \multicolumn{7}{|c|}{ ANOVA $^{\circ}$} \\
\hline Model & & $\begin{array}{c}\text { Sum of } \\
\text { Squares }\end{array}$ & df & $\begin{array}{l}\text { Mean } \\
\text { Square }\end{array}$ & $\mathrm{F}$ & Sig. \\
\hline \multirow[t]{3}{*}{1} & Regression & 3436.636 & 3 & 1145.545 & 64.476 & $.000^{a}$ \\
\hline & Residual & 817.284 & 46 & 17.767 & & \\
\hline & Total & 4253.920 & 49 & & & \\
\hline
\end{tabular}

Dari hasil analisis dengan menggunakan Komputer program Statistical Package for Social Sciences (SPSS) Versi 24 for windows yakni uji ANOVA atau $\mathrm{F}_{\text {hitung }}$ variabel Kualitas Produk $\left(\mathrm{X}_{1}\right)$ dan variabel Harga $\left(\mathrm{X}_{2}\right)$ dan Iklan $\left(\mathrm{X}_{3}\right)$ secara bersama-sama atau simultan ada terhadap Kepuasan Pembelian (Y) di peroleh nilai sebesar 64,475 dimana lebih besar dari $\mathrm{F}_{\text {tabel (49) }}$ sebesar 2,795 dengan tingkat signifikan sebesar 0,000 karena $0,000<0,05$, maka dapat dikatakan variabel Kualitas Produk $\left(\mathrm{X}_{1}\right)$, variabel Harga $\left(X_{2}\right)$ dan Iklan $\left(X_{3}\right)$ secara bersama-sama atau simultan ada terhadap Kepuasan Pembelian (Y).

\section{KESIMPULAN DAN SARAN \\ Kesimpulan}

Berdasarkan pada hasil analisa dan pembahasan penulis akan menarik suatu kesimpulan. Adapun kesimpulannya sebagai berikut :

1. Berdasarkan pada hasil analisa korelasi parsial dinyatakan terdapat pengaruh positif antara variabel Kualitas Produk terhadap Kepuasan Pembelian diperoleh nilai sebesar 0,830 sehingga dapat disimpulkan bahwa tingkat pengaruhnya sangat kuat atau diperoleh nilai Koefisien Determinasi sebesar 68,9\%. Maka dilakukan uji hipotesis variabel Kualitas Produk Terhadap Kepuasan Pembelian diperoleh nilai $t_{\text {hitung }}$ 
sebesar $=4,994>\mathrm{t}_{0,05(48)}=1,6821$ maka $\mathrm{H}_{\mathrm{o}}$ ditolak dan $\mathrm{H}_{\mathrm{a}}$ diterima berarti mempunyai cukup bukti bahwa ada pengaruh signifikan.

2. Sedangkan hasil analisa korelasi parsial dinyatakan terdapat pengaruh positif antara variabel Harga Terhadap Kepuasan Pembelian diperoleh nilai sebesar 0,825 sehingga dapat disimpulkan bahwa pengaruhnya kuat atau diperoleh nilai Koefisien Determinasi sebesar $68,1 \%$. Dibuktikan dengan uji hipotesis variabel Harga Terhadap Kepuasan Pembelian diperoleh nilai $\mathrm{t}_{\text {hitung }}=4,444>\mathrm{t}_{0,05(48)}=1,682{\text { maka } \mathrm{H}_{\mathrm{o}}}$ ditolak dan $\mathrm{H}_{\mathrm{a}}$ diterima yang berarti mempunyai bukti, bahwa ada pengaruh signifikan.

3. Sedangkan hasil analisa korelasi parsial dinyatakan terdapat pengaruh positif antara variabel Iklan terhadap Kepuasan Pembelian diperoleh nilai sebesar 0,850 sehingga dapat disimpulkan bahwa pengaruhnya kuat atau diperoleh nilai Koefisien Determinasi sebesar $72,2 \%$. Dibuktikan dengan uji hipotesis variabel Iklan terhadap Kepuasan Pembelian diperoleh nilai $\mathrm{t}_{\text {hitung }}=4,633>\mathrm{t}_{0,05(48)}=1,701{\text { maka } \mathrm{H}_{\mathrm{o}}}$ ditolak dan $\mathrm{H}_{a}$ diterima yang berarti mempunyai bukti, bahwa ada pengaruh signifikan.

4. Secara simultan berpengaruh positif antara variabel Kualitas Produk, Harga dan Iklan terhadap Kepuasan Pembelian diproeses dengan komputer program Statistical Package for Social Sciences (SPSS) Versi 24 for Windows diperoleh nilai Model Summary atau nilai $\mathrm{R}$ sebesar 0,899 dan sedangkan nilai $\mathrm{R}$ Square sebesar 0,808 atau $80,8 \%$, jadi pengaruhnya sangat kuat. Dibuktikan dengan uji ANOVA atau $\mathrm{F}_{\text {hitung }}$ variabel Kualitas Produk, variabel Harga dan Iklan terhadap Kepuasan Pembelian di peroleh nilai sebesar 64,476 dimana lebih besar dari $\mathrm{F}_{\text {tabel (49) }}$ sebesar 2,795 dengan tingkat signifikan sebesar 0,000 karena $0,000<0,05$, maka dapat dikatakan secara bersama-sama berpengaruh sangat signifikan.

\section{Saran}

Bab penutup dari penelitian ini, penulis mencoba memberikan saran-saran yang mungkin berguna baik bagi penulis maupun bagi sekolah. Adapun saransaran adalah sebagai berikut :

1. Pimpinan PT. Askotama Inti Nusantara yang saat ini pemasarannya dengan Kualitas Produk sudah baik dalam meningkatkan kepusan Pembelian. Namun diharapkan kedepannya Kualitas Produk lebih ditingkatkan lagi agar di masa mendatang kepuasan Pembelian akan lebih optimal lagi sebagaimana yang di harapakan semuah pihak ataupun pimpinan perusahaan.

2. Pimpinan PT. Askotama Inti Nusantara hendaknya terus meningkatkan Harga sudah sangat baik dan perlu dipertahanklan atau bila perlu lebih ditingkatkan di masa yang akan datang agar kepuasan Pembelian sesuai apa yang diharapkan pimpinan dengan Harga lebih baik secara nyata kepuasan Pembelian akan lebih meningkat sebagaimana yang harapan.

3. Pimpinan PT. Askotama Inti Nusantara hendaknya terus meningkatkan Iklan sudah sangat baik dan perlu dipertahanklan atau bila perlu lebih ditingkatkan di masa yang akan datang agar kepuasan Pembelian sesuai apa yang diharapkan pimpinan dengan Iklan lebih baik secara nyata kepuasan Pembelian akan lebih meningkat sebagaimana yang harapan.

4. Secara keseluruhan pimpinan dan karyawan PT. Askotama Inti Nusantara hendaknya terus meningkatkan Kualitas Produk, mempertahankan Harga dan Iklan yang saat ini sudah sangat baik hal ini terlihat dari hasil analisisnya yang diperoleh nilai korelasi yang tinggi atau bila perlu terus ditingkatkan Kualitas Produkdan kualitas pelayanannya di masa yang akan datang akan lebih optimal lagi tingkat kepuasan Pembeliannya akan lebih optimal lagi sebagaimana yang di harapkan pimpinan perusahaan kedepannya.

\section{DAFTAR PUSTAKA}

Arikunto, Suharsimi, 2014., Prosedur Penelitian Suatu Pendekatan Praktek. Badan Penerbit Rineka Cipta. Jakarta.

Hatane Samuel, Perilaku dan Keputusan Pembelian Konsumen, Surabaya : Jurnal Manajemen pemasaran,2007, hal 75 .

Bambang Istianto, 2011, Manajemen Pemerinthan dalam Prespektif Pelayanan Publik, Badan Penerbit Mitra Wacana Media, Jakarta.

Buchari Alma, 2013, Manajemen Pemasaran, Badan Penerbit PT. Gelora Antara Pratama, Jakarta.

Fandy. Tjiptono, 2017. Prinsip \& Dinamika Pemasaran. Edisi Pertama. Badan Penebit J \& J Learning. Yogyakarta.

Freddy Rangkuti, 2015, Teknik Mengukur dan Strategi Meningkatkan Kepuasan Pelangan”, Badan Penerbit PT Gramedia Pustaka Utama, Jakarta. 
Hadari Nawawi, 2012. Kualitas ProdukMenurut Islam, Badan Penerbit Gadjah Mada University press, Yogyakarta.

Husein Umar, 2010. Riset Sumber Daya Manusia Dalam Organisasi, Badan Penerbit Rajawali Pers. Jakarta.

J. Supranto, 2015. Metodologi Ramalan Kuantitatif untuk Perencanaan Ekonomi dan Bisnis, Badan Penerbit PT. Rineka Cipta. Jakarta.

Kotler and Amstrong 2008, Manajemen Pemasaran, Badan Penerbit PT. Gelora Antara Pratama, Jakarta.

Kotler, Philip., 2014. "Manajemen Pemasaran, Analisis, Perencanaan, Implementasi dan Pengendalian”, Alih Bahasa Jaka Wasana, Badan Penerbit PT. Gelora Antara Pratama, Jakarta.

Kotler, Philip Gary Armstrong, 2008, Prinsip-prinsip Pemasaran, Badan Pebnerbit Erlangga. Jakarta.

Machfoedz, 2013, Respnse determinant in Satisfaction Judgments, Jouenal of Consumer research, Vol 14 (Masch) PP. 495-507.

Mohamad. Nazir, 2010. Metode Penelitian, Badan Penerbit Ghalia Indonesia, Jakarta.

Mulia Nasution, 2012, Manajemen Pemasaran, Dasar Konsep dan Strategi, Penerbit CV. Rajawali Pers, Jakarta,
Parasurahman, Zeithaml dan Berry dalam Hans, 2009, Pelayanan Pembelian yang Sempurna, Badan Penerbit Kunci Ilmu, Yogyakarta.

Schiffman dan Kanuk, 2009, Costumer Bahavior. Seven Edition, Prentice Hall International, inc. Upper Saddle River. New Jersey.

Sonny Harsono, 2010, Skala Pengukuran Variabelvariabel Penelitian, Badan Penerbit, ALFABETA, Bandung.

Sugiyono, 2016, Metode Penelitian Bisnis, Badan Penerbit ALFABETA. Bandung.

Sutisna, 2011, Manajemen Pemasaran dan Analisis Perilaku Konsumen, Badan Penerbit, CV. Intermedia Jakarta.

Ujang Sumarwan, Perilaku Konsumen, Bogor: Badan Penerbit Ghalia Indonesia, hal.310.

Tjahya.Supriatna, 2016, Manajemen Loyalitas, dan Sumberdaya Aparatur, Badan Penerbit. CV. Indra Prahasta, Bandung.

Keterangan lebih rinci dapat diakses dari : http:// id.shvoong.com/internet-and-technologies/ commercialcompanies/2043787-pengertianiklan/

http://whatisiqeqsq.blogspot.com/, Di akses pada Tanggal 10 September, 2021 
